\title{
Norma podstawowa w Czystej Teorii Prawa Hansa Kelsena
}

\author{
Marta Zuzanna Huk (Adam Mickiewicz University in Poznań)
}

Norma podstawowa jest gwarantem obowiązywania systemu prawa nie tylko z uwagi na swoją abstrakcyjną konstrukcję, lecz także ze względu na sposób jej założenia, ściśle związany $\mathrm{z}$ dynamicznym charakterem prawa. Innymi słowy, Grundnorm przyczynia się do legitymacji obowiązywalności innych norm porządku prawnego nie dlatego, że ich treść może być logicznie wywiedziona z normy podstawowej, lecz z uwagi na to, że zostały one stworzone, czyli ukonstytuowane w określony sposób właśnie przez normę podstawową. Według Kelsena jest to jedyna przyczyna ich obowiązywania, co implikuje założenie, że każda treść może w określonych warunkach stać się prawem (Kelsen 2009, 198). Autor potwierdza tę tezę obserwacją, że wszelkie ludzkie zachowanie, na mocy własnej treści, ma potencję do bycia prawem. Należy zatem zadać sobie pytanie o to, w jaki sposób powinność (ujęta później w ramy normy prawnej) zyskuje faktyczną moc normotwórczą. Pierwszym i zarazem najważniejszym założeniem Grundnorm jest ograniczenie jej funkcji do legitymizowania procesów tworzenia prawa. Staje się więc zasadą, na mocy której powinny być tworzone wszystkie normy danego porządku. Zatem norma podstawowa rozumiana jest jako założenie o ważności sposobu stanowienia i legitymizowania porządku prawnego (Kelsen 2009, 197).

Wszystkie kolejne normy danego porządku będą normami prawa stanowionego, rozumianymi jako uregulowany zbiór elementów prawa pozytywnego. Grundnorm stanowi konstytucję dla całego porządku normatywnego, jednakże jej natura jest logiczno-prawna, a nie pozytywnoprawna (Spaak 2005, 402), co oznacza, że nie może być ona tożsama z konstytucją w sensie politycznym. Innymi słowy, jeśli porządek normatywny jest systemem prawa stanowionego lub, pośrednio, zwyczajowego, to dla jego wewnętrznej spójności oraz $\mathrm{z}$ uwagi na konieczność ujednoliconej legitymizacji obowiązywania, niezbędne jest założenie czegoś jeszcze "przed” owym porządkiem. Owo „coś” musi być, po pierwsze, całkowicie autonomiczne, pod drugie - możliwie jak najogólniejsze, po trzecie zaś, musi mieć zdolność nie tylko do obowiązywania, lecz także do uzasadniania obowiązywania całego porządku normatywnego. Na mocy uprzednich założeń Kelsena wiadomo, że podstawą obowiązywania jednej normy prawnej może być jedynie inna norma prawna, która jest względem niej wyższa ogólniejsza. Nie może to być jednak norma stanowiona, 
ponieważ implikowałoby to konieczność jej legitymizacji. A skoro to ona ma być źródłem legitymizacji, to znaczy, że powinna być jedynie założona. W ten sposób staje się pozbawioną treści konstytucją obowiązywania prawa stanowionego, ujmowanego holistycznie. Norma podstawowa jest zatem normą ustanawiającą, a nie ustanawianą przez porządek prawny jako taki. Oznacza to, że norma prawna daje także upoważnienie do aktu stanowienia prawa - staje się legitymizacją prawodawcy (Duxbury 2007, 5-7).

Tym samym wytwarza się swoisty schemat obowiązywania, dla którego można założyć, że dana norma A jest normą indywidualną konkretnego porządku prawnego. Jej bezpośrednią podstawą obowiązywania jest zatem norma generalna B. 0 ile jednak należy założyć, że $B \rightarrow A$, o tyle trzeba zadać sobie pytanie o źródło legitymizacji normy B. Za jej podstawę obowiązywania można uznać określony akt prawny, na mocy którego norma $B$ jest ważna czyli akt $C$, wówczas: $B \in C$, czyli $(B \rightarrow A) \in C$. Legitymizacja aktu $C$ ma swoje podstawy w kolejno wyższych aktach prawnych, tj. D, E i F1. Łańcuch ten dochodzi aż do normy kompetencyjnej, czyli takiej, która upoważnia dany organ do stanowienia prawa, co równa się konieczności założenia pewnej normy n, która umożliwia interpretację wszystkich tych norm, które zostały ustanowione na mocy jej wewnętrznej konstrukcji (Kelsen 2009, 199-201).

Faktyczne obowiązywanie Grundnorm uzależnione jest zatem od dwóch czynników: po pierwsze, musi być ona założona jako pierwotna względem prawa stanowionego lub zwyczajowego regulującego zachowania i powinności oraz po drugie - konstrukcja normy wymaga, aby była ona pozbawiona treści, co gwarantuje skuteczność obowiązywania prawa o charakterze dynamicznym. Innymi słowy, poszczególne normy stanowią prawo nie dlatego, że wynikają logicznie z treści norm hierarchicznie wyższych, lecz dlatego, że podstawą ich obowiązywania są inne normy prawne (Kelsen 2009, 200; por. Hughes 1971, 695-678).

\section{Założenie transcendentalno-logiczne}

Rozważania dotyczące istoty normy podstawowej w naturalny sposób rodzą filozoficzne konsekwencje. Z obiektywnego, filozoficzno-prawnego punktu widzenia, powinny one czerpać swoje źródła na gruncie pytań o to, w jaki sposób Grundnorm gwarantuje logiczną niesprzeczność porządku prawnego oraz, ogólniej rzecz ujmując, czym jest Kelsenowskie aprioryczne założenie identyfikowane z normą podstawową.

Chcąc poznać istotę Grundnorm należy zauważyć, że istnieje ona zawsze w odniesieniu do ustanowionego porządku prawnego, co oznacza, że każdy skuteczny i usankcjonowany porządek wymuszony tworzony jest przez

1 Gdzie dla uzasadnienia obowiązywania każdego niższego aktu zachodzi relacja zawierania się w akcie o wyższym stopniu uogólnienia: $\mathrm{F} \rightarrow \mathrm{E} \rightarrow \mathrm{D}$, etc. 
określoną normę leżącą u jego podstaw. Nie można zatem orzec o niej, że powstaje $\mathrm{w}$ wyniku spontanicznego odkrycia (product of free invention). Aspekt wolicjonalny jej założenia rozumiany jest raczej jako możliwość dokonania wyboru między różnymi normami podstawowymi (Kelsen $2009,201)$ w procesie subiektywnej interpretacji aktu konstytuującego ów wymuszony porządek. Innymi słowy, na Grundorm nakładane jest ograniczenie wynikające $\mathrm{z}$ faktu konieczności stworzenia konstytucji gwarantującej ważność i skuteczność prawnego porządku wymuszonego. Norma podstawowa musi być zatem założeniem adekwatnym do wytwarzanego przez siebie porządku. Otóż jedynie założenie normy podstawowej jako legitymizacji konstytucji, rozumianej jako założenia przestrzegalności owej konstytucji, gwarantuje prawidłową wykładnię obiektywnie obowiązujących norm prawnych (Duxbury 2007, 3-4). Z perspektywy czystej teorii prawa ani treść, ani moralny status konstytucji nie odgrywają żadnej roli dla poznania prawnego, co w konsekwencji oznacza, że założenie normy podstawowej nie może być tożsame $\mathrm{z}$ wytworzeniem lub potwierdzeniem wartości transcendentnej prawa pozytywnego (Kelsen 2009):

Jak dotąd, jedynie założenie normy podstawowej czyni możliwym interpretowanie subiektywnego znaczenia aktu konstytuującego tworzenie porządku (oraz aktu ustanowionego, zgodnego z ową konstytucją), jako obiektywnego znaczenia, czyli jako obiektywnie ważnej normy prawnej; i jeśli zasadna jest analogia do koncepcji epistemologii Kanta, norma prawna może być wykorzystywana przez naukę prawa jako transcendentalno-logiczny warunek owej interpretacji (201-202).

Warunek transcendentalno-logiczny, odsyłający do koncepcji Kanta, rozumiany jest jako pytanie o sposób, w jaki ma być możliwa interpretacja faktów konstruowanych w poznaniu zmysłowym, która przejawiałaby się wyłącznie na gruncie epistemologicznym, całkowicie wolna od założeń metafizycznych (por. Brueckner 1983, passim; Brueckner 1984, passim). Kelsen przenosi kantowski warunek na grunt czystej teorii prawa, szukając odpowiedzi na pytanie: w jaki sposób możliwe jest poznanie i subiektywna interpretacja stanów faktycznych, opisywanych za pomocą obiektywnych norm prawnych, które nie byłoby oparte na meta-prawnych założeniach o autorytecie (takich, jak Bóg czy Natura)(Kelsen 2009, 202)?

Odpowiedzią na Kelsenowskie pytanie jest zgodny z Arystotelesowską sylogistyką porządek obowiązywania ustanowiony na mocy założenia Grundorm. Otóż każda subiektywna interpretacja stanu faktycznego, który wyrażany jest za pomocą zobiektywizowanej normy powinnościowej, bierze swoje źródła w konstytucji, która stanowi o obiektywności, obowiązywalności i ważności norm prawnych danego porządku. Zatem założenie normy 
podstawowej głoszącej, że każdy człowiek powinien przestrzegać konstytucji (w najszerszym sensie-na gruncie nie tylko czynności, lecz zachowania w ogóle) oznacza tyle, że każde zachowanie powinno być dyktowane przez akt woli kreujący w znaczeniu subiektywnym właśnie tę konstytucję. Funkcją Grundnorm jest więc ugruntowanie obiektywnej ważności systemu prawa pozytywnego, czyli subiektywnego znaczenia czynności wynikających z aktów woli, rozumianych jako wytwarzaną strukturę wymuszonego porządku normatywnego (Kelsen 2009, 202). Odwoływanie się do meta-prawnych autorytetów okazuje się być niekonieczne wówczas, gdy gwarantem skuteczności owej konstytucji jest aksjologicznie neutralne założenie normy podstawowej. Grundnorm staje się aktualizacją Kantowskiego warunku transcendentalno-logicznego, na mocy którego zyskuje ona funkcję uzasadniania obiektywnie obowiązującej normy prawnej (Spaak 2007, 404405). Struktura sylogizmu wymaga, aby normatywny ciąg argumentacyjny był logiczny i niesprzeczny, co w języku czystej teorii oznacza, że obowiązywalność normy niższej gwarantowana jest przez obowiązywalność normy hierarchicznie wyższej. Konieczne jest zatem pomyślenie lub taka artykulacja Grundnorm, która stanowi podstawę dla logicznej niesprzeczności wypowiedzi argumentacyjnej (Kelsen 2014, 307-310).

Norma podstawowa nie może być jednak, z uwagi na swoją konstrukcję, normą pożądaną z perspektywy prawoznawstwa. Oznacza to, że sama w sobie nie jest przedmiotem poznania, lecz stanowi warunek jego możliwości i skuteczności. Jej wysłowienie pozostaje jednak niezbędne dla logicznego uzasadnienia porządku prawa pozytywnego. Specyfika owego wysłowienia oznacza, że według Kelsena może się ono ograniczać jedynie do jej pomyślenia - założenia, działającego na zasadzie podstawy interpretacyjnej, naturalnie subiektywnej dla ujmowanego holistycznie, obiektywnego systemu prawa. Autor zaznacza, że stwierdzenie istnienia normy podstawowej dla każdego porządku prawnego nie stanowi nowego schematu interpretacyjnego. Założenie transcendentalno-logicznej normy podstawowej wymuszonego porządku jest jedynie logicznym zabiegiem, mającym na celu zupełną normatywizację prawa (Kelsen 2009, 204-205).

Realizacja porządku prawnego na poziomie teoretycznym ma dla Kelsena wymiar czysto logiczny, albowiem czysta teoria bazuje na prawach logiki klasycznej. Jednakże z uwagi na specyfikę badanej przez siebie dziedziny wymaga ich elastycznej reinterpretacji. Naczelnym logicznym założeniem normatywizmu jest mianowicie teza o uzasadnianiu podstawy obowiązywania, wyrażającej się w relacji pomiędzy Grundnorm a normami prawa pozytywnego: jak już wykazano wcześniej, podstawą obowiązywania wszystkich norm prawnych danego porządku jest taka norma podstawowa, która gwarantuje ich jedność. Oznacza to, że porządek może być opisywany w kategoriach prawnych za pomocą zdań, które są wzajemnie niesprzeczne (Kelsen 2009, 205). Założenie to, w żadnym wypadku nie jest tożsame ze 
stwierdzeniem, że poszczególne normy nie mogą pozostawać ze sobą w konflikcie. Wręcz przeciwnie: sprzeczność norm występuje w praktyce każdorazowo, gdy to samo zachowanie jest określane przez jedną normę jako pożądane, a przez inną jako niepożądane. Taki konflikt nie stanowi jednak o sprzeczności w ścisłym znaczeniu tego pojęcia. Logiczna sprzeczność zdań występuje jedynie wtedy, gdy jedno zdanie jest prawdziwe, a drugie fałszywe ${ }^{2}$. Jednak norma prawna, jako zdanie powinnościowe (preskryptywne), nie może być ani prawdziwa, ani fałszywa; może być jedynie obowiązująca lub nieobowiązująca. Jednak celem normy prawnej jest wywołanie, poprzez akt przymusu, danego stanu faktycznego, który sam w sobie może mieć określony status logiczny (Green 2003, 373-379). Jest to powód, dla którego zdania wyrażające (Rechtsnorm) i opisujące (Rechtsatz) normy (a zatem pośrednio same normy prawne) mogą stosować się do zasad logiki. Wynika stąd, że uznanie dwóch wykluczających się $e^{3}$ norm prawnych za wzajemnie sprzeczne nie jest błędem w rozumieniu czystej teorii prawa. Zdanie mówiące, że „dana powinność zarazem jest i nie jest” (a właściwie zachodzi i nie zachodzi), jest takim samym nonsensem jak zdanie „dany stan faktyczny jest i zarazem nie jest". Konflikt norm powinnościowych ukazuje wyrażenie bezsensowne w sposób analogiczny do sprzeczności logicznej zdań deskryptywnych (Kelsen 2009, 206).

Roszczenie prawoznawstwa do poznania istoty prawa jako sensownej i spójnej całości zmusza do przyjęcia założenia o rozstrzyganiu konfliktów na poziomie interpretacyjnym. Kelsen rozróżnia tu dwa rodzaje konfliktów, zależne od relacji łączących wzajemnie sprzeczne normy. Pierwszy konflikt wystąpić może między normami tego samego poziomu, np. normami o tym samym stopniu obowiązywalności, co uniemożliwia wskazanie jednej z nich jako hierarchicznie wyższej. Zatem w przypadku dwóch norm generalnych, ustanowionych przez ten sam organ prawodawczy w różnym czasie, w myśl zasady lex posteriori derogat priori, norma późniejsza uchyla wcześniejszą. Jednak jeśli dwie normy generalne będą jedynie częściowo sprzeczne, np. „każdy, kto dopuszcza się czynu zabronionego powinien ponieść karę” oraz „osoby małoletnie nie podlegają karze”, to należy przyjąć, że druga norma ogranicza obowiązywanie pierwszej, poprzez dookreślenie jej zakresu kompetencji, np. „każdy, kto dopuszcza się czynu zabronionego, z wyjątkiem osób małoletnich, podlega karze". W przypadku, gdy nie wystąpi żadna z powyższych interpretacji, następuje nonsensowny akt normotwórczy, a-w konsekwencji-żaden akt normotwórczy nie może tu mieć miejsca (Kelsen 2009, 207).

W przypadku konfliktu dwóch norm indywidualnych rozwiązanie prawne nie jest bezwzględnie skuteczne. Dotyczy to szczególnie przypadku, gdy normy zostały ustanowione przez dwa niezależne od siebie organy władzy.

${ }^{2}$ Co wynika choćby z zasady niesprzeczności: $\sim(\mathrm{p} / \sim \mathrm{p})$.

${ }^{3}$ Niezależnie, czy sprzeczność zachodzi w dyspozycji, czy też w sankcji danej normy. 
Przyjmuje się wówczas rozwiązanie arbitralne, na mocy którego sankcja może, lecz nie musi zostać wyegzekwowana. Interpretacja przebiega więc zgodnie z założeniami normy podstawowej, która określa charakter przymusu zgodny z normami generalnymi i, pośrednio, konstytucją (Kelsen 2009, 207-208).

Konflikt nie może natomiast zaistnieć pomiędzy normami różnego poziomu, z racji założenia, w myśl którego norma hierarchicznie wyższa wyznacza zakres kompetencji normy niższej, a zatem wyznacza jej zakres regulacji. Wynika stąd, jak już poprzednio wykazano, że norma wyższa jest jedyną i bezwzględną podstawą obowiązywania normy niższej.

\section{Efektywność normy podstawowej}

To, jak doniosła jest norma podstawowa dla każdego porządku prawnego, staje się widoczne w obliczu znaczących przemian politycznych i prawnych. Kelsen, jako wybitny konstytucjonalista, w celu egzemplifikacji tej tezy posługuje się właśnie pojęciem konstytucji rozumianej jako akt prawny wynikający bezpośrednio z Grundnorm.

Na mocy zasad logiki istnienie normy prawnej jest uzależnione nie tylko od obowiązywalności normy bezpośrednio wyższej, lecz także od statusu całego porządku prawnego. Zakres obowiązywania każdej normy prawnej wyznaczany jest zatem na każdym poziomie ciągłością obowiązywania normy hierarchicznie wyższej. Zatem podważenie konstytucji, rozumianej tu jako pojedyncza, generalna norma gwarantująca legalność systemu prawnego jest tożsame z podważeniem obowiązywalności całości porządku prawnego. To właśnie porządek prawny, mając zdolność do samoregulacji, określa początek i koniec obowiązywania swoich norm. Gwarantem ciągłości staje się więc konstytucja, rozumiana jako wysłowienie warunków obowiązywania norm i skuteczności systemu:

Zasada głosząca, że dana norma należy do określonego porządku prawnego jest ważna tak długo, jak jej ważność jest determinowana przez ten porządek prawny lub zastąpiona przez ważność innej normy tegoż porządku, nazywana jest zasadą legitymizacji (Kelsen 2009, 209).

Zasada legitymizacji, nazywana także zasadą legalności (por. ibid. 316), podlega znacznym ograniczeniom. Według Kelsena nie znajduje ona żadnego zastosowania w przypadku rewolucji, która chce podważać obowiązywanie całego porządku praw włącznie z konstytucją. W tym punkcie Kelsen podąża śladem Kanta, przy czym Kant argumentuje, że system prawny i konstytucja nie mogą zawierać klauzul umożliwiających pozbawienie go ważności poprzez rewolucję. Należy wobec tego zauważyć, że rewolucja (i podobnie nieposłuszeństwo obywatelskie) nie są i nie mogą być „legalne”. Oznacza to, że wszczęcie i przebieg rewolucji (na mocy definicji pojęcia) są 
sprzeczne z zasadami przyjętymi w konstytucji. Jednak z perspektywy Kelsena faktem całkowicie irrelewantnym jest sposób zmiany sytuacji prawnej. Istotnym punktem jest natomiast pojęcie zmiany lub zastąpienia dotychczasowego nowym porządkiem prawnym w myśl zasad, które nie były wysłowione w konstytucji. Kelsen opisuje to zjawisko jako całkowite lub częściowe stwarzanie nowego prawa (Paulson 2013, 29-31). Na podstawie założeń autora, przykładem stwarzania porządku prawnego całkowicie de novo i zgoła ex nihilo może być rewolucja październikowa, podczas gdy przykładem częściowego stwarzania, kojarzącego się z przyspieszoną ewolucją zdaje się być recepcja prawa rzymskiego w Europie. Rewolucja i ewolucja to pojęcia wzajemnie się uzupełniające na gruncie jego normatywizmu.

Kluczowy dla czystej teorii jest natomiast fakt, że z chwilą przyjęcia przez państwo nowej konstytucji, zmienia się norma podstawowa. Grundnorm musi ulec zmianie, ponieważ jako najwyższy gwarant obowiązywalności danego (jedynego) porządku prawnego, nie może rościć sobie praw do zmiany wektora legitymizacji. Implikacja dla tego przypadku wygląda następująco: zmiana konstytucji wymaga zmiany normy podstawowej, co z kolei zmienia nie tylko cały porządek normatywny, lecz także wpływa na wywoływane przez niego stany faktyczne; zmiana następuje zatem wobrębie całego schematu interpretacyjnego prawa (Kelsen 2009, 209-210). Oznacza to, że nowa norma podstawowa staje się przyczyną legalności nie tylko nowej konstytucji i porządku prawnego, lecz także organu prawodawczego i, pośrednio, wywoływanego przez wszystkie wyżej wymienione czynniki stanu faktycznego. W omawianym wypadku, zmiana Grundnorm następuje wszak dopiero po zmianie faktycznej, jaką jest społeczny aspekt rewolucji. Znajduje ona swoje odniesienie przedmiotowe w konstytucji, która została faktycznie ustanowiona, za pomocą aktu lub zwyczaju, a zarazem, która jest skuteczna. O skuteczności konstytucji można mówić wówczas, gdy stanowione przez nią i zgodnie z nią normy prawne istotnie obowiązują.

Dla Kelsena skuteczność konstytucji, a pośrednio także założenia Grundnorm i wywołanie pożądanego stanu faktycznego podpadają pod miano efektywności lub skuteczności. Uwidacznia to m.in., że zasada legitymizacji ograniczana jest zasadą efektywności (principle of effectiveness) (Kelsen 2009, 211), co jednak jest charakterystycznym przejawem pozytywistycznej koncepcji prawa, nieco analogicznym do przewagi bezpieczeństwa nad celowością prawa i sprawiedliwością.

\section{Ważność normy podstawowej}

4 W odróżnieniu od ważności (związanej wyłącznie na poziomie teoretycznym z pojęciem obowiązywalności), efektywność lub skuteczność normy dotyczy jej odniesienia faktycznego. 
Czysta teoria prawa w sposób jednoznaczny odróżnia pojęcie ważności, tj. obowiązywalności normy, od opisanego powyżej pojęcia efektywności, tj. skuteczności (por. Kelsen 2014, passim). Właściwe określenie tej relacji jest jednym z największych wyzwań dla prawa pozytywnego. Problem ten ma szczególne znaczenie dla poznania prawnego, gdyż stanowi szczególny przypadek stosunku zachodzącego między rzeczywistościami powinności i bytu. W celu właściwego zarysowania omawianej dystynkcji, wraz zjej konsekwencjami, należy ustalić, w jaki sposób możliwe jest zaistnienie takiego związku. Otóż wydanie aktu prawnego mocującego daną normę ma jednocześnie znaczenie zarówno dla sfery powinności z uwagi na konstrukcję i ważność normy jako takiej, jak i dla sfery bytu, z uwagi na uznanie aktu oraz skuteczności normy prawnej za fakt ontyczny (Kelsen 2009, 211).

Teoria prawa pozytywnego znajduje się zatem w takiej sytuacji, która niezbędnie wymaga wypracowania kompromisu między skrajnymi poglądami: z jednej strony, zasadną może się wydawać teza, jakoby między ważnością normy, istniejącą w sferze powinności oraz jej efektywnością, istniejącą w sferze bytu, nie istniał żaden związek. Z drugiej strony, pojawia się tendencja do utożsamiania ze sobą pojęć ważności i efektywności. Według Kelsena fakt, że zarówno norma prawna, jak i cały porządek tracą swoją ważność, tracąc efektywność, przemawia za odrzuceniem pierwszej koncepcji. A zatem, zachodzenie realnego związku obowiązywalności i skuteczności normy przesądza o fałszywości pierwszej tezy. Druga teza również okazuje się fałszywa - istnieją bowiem przypadki, dla których dana norma obowiązuje, pomimo iż nie jest (lub jeszcze nie jest) skuteczna. Czysta teoria prawa, wypracowując pożądany kompromis, zajmuje w tej kwestii następujące stanowisko:

W taki sam sposób jak norma (oznaczająca powinność), jako znaczenie aktu nie jest z nim identyczna ..., tak ważność normy prawnej nie jest identyczna z jej efektywnością ... (Kelsen 2009, 211).

Zatem efektywność pojedynczej normy oraz efektywność całego porządku normatywnego jest warunkiem ważności, tak samo jak ważność (a właściwie racja, dla której norma czy porządek zyskuje ważność) warunkuje efektywność. Teza ta zawiera odpowiedź na pytanie o to, dlaczego porządek prawny traci swoją ważność, gdy traci skuteczność; porządek normatywny przestaje być skuteczny wówczas, gdy podstawa, na której został zbudowany, tj. Grundnorm, staje się nieadekwatna. Kiedy zaś, ze względu na swoją konstrukcję, norma podstawowa nie może być efektywna, traci ona swoją ważność w tym znaczeniu, że nie wywołuje już obowiązywalności pośród

${ }^{5}$ Pierwsza teza została wypracowana na gruncie idealistycznym, podczas gdy druga jest wynikiem założeń teorii realistycznych. 
pozostałych norm danego porządku6. Skuteczność jest zatem warunkiem obowiązywania normy, wskutek którego porządek prawny utrzymuje swoją ważność. Jednak analogicznie, gdy norma traci rację gwarantującą jej ważność, nie może być efektywna. Należy jednak pamiętać, że warunek nie jest tożsamy z tym, co jest warunkowane. Wzajemne warunkowanie ważności i skuteczności porządku normatywnego z perspektywy normy podstawowej może zostać wyrażone następującym sylogizmem:

1) Przesłanka entymematyczna-wyrażenie powinności: Należy zachowywać się zgodnie z ustanowioną i skuteczną konstytucją (zdanie to wyraża strukturalne założenie Grundnorm).

2) Założenie sylogizmu: Stanowioną podstawą tworzenia porządku prawa jest konstytucja.

3) Wniosek sylogizmu—zdanie ontyczne: Konstytucja jest faktycznie ustanowiona i skuteczna.

4) Konkluzja sylogizmu: Porządek prawny obowiązuje, co oznacza, że jest ważny (por. Kelsen 2009, 212).

Powyższy schemat ilustruje zależności zachodzące między efektywnością (skutecznością), a ważnością (obowiązywalnością) norm w porządku prawnym. Najważniejszym wnioskiem dla czystej teorii prawa jest zatem stwierdzenie, że Grundnorm gwarantuje nie tylko ważność, ale i pierwotną względem niej efektywność.

Stwierdzenie obowiązywania prawa jest w rzeczywistości stwierdzeniem jego istnienia. Istnienie to nie może być wyartykułowane w pojęciach właściwych dla sfery bytu, stąd mawia się często, że prawo odnosi się lub przeciwstawia rzeczywistości. Taka teza nie miałaby sensu w sytuacji, gdy ważność prawa byłaby utożsamiana ze skutecznością. W jaki bowiem sposób rzeczywistość może zawierać wewnętrzną sprzeczność logiczną? Jednak abstrahowanie od rzeczywistości na poziomie ustanawiania obowiązywalności prawa nie jest możliwe. W miejsce rzeczywistości rozumianej fenomenalnie należy wstawić pojęcie skuteczności jako przejawu obowiązywalności prawa w sferze bytu (Green 2003, 381-382).

Podsumowując należy jednak pamiętać, iż pomimo częstej złożoności tego problemu, jedynie wyraźny rozdział i określenie warunków, dla których ważność i efektywność normy mogą się zazębiać, stanowi o zarówno wewnętrznej niesprzeczności, jak i równoczesnej spójności prawa na dwóch

6 Sytuacją analogiczną będzie zatem utrata skuteczności jednej z norm danego porządku: gdy norma A traci swoją skuteczność, to podstawa, na której została ona ustanowiona-norma B-„traci” dla tej normy swoją obowiązywalność, a ściślej: przestaje konstytuować ważność normy A. Nie wynika stąd jednak, że porządek prawny traci swoją ważność z powodu zakończenia obowiązywalności jednej ze swoich norm. Norma ta przestaje być stosowana, a w jej miejscu pojawia się nowa skuteczna norma prawna. W praktyce, nieobowiązującymi normami są te, które są jednocześnie nieskuteczne i niestosowane lub nieprzestrzegane. Następuje wówczas sytuacja zwana desuetudo tj. uchylenie normy. 
płaszczyznach ontologicznych, rozumianych przez Kelsena jako sfery bytu i powinności.

\section{Literatura}

Brueckner, A. 1983. “Transcendental Arguments”, II. Noûs 17.

- - - 1984. "Transcendental Arguments", II. Noûs 18.

Bryan, I., Langford, P. 2013. "Hans Kelsen's Concept of Normative Imputation." Ratio Juris 26(1).

Dore, I.I. 2007. The Epistemological Foundations of Law. Durham: Carolina Academic Press.

Duxbury, N. 2007. "The Basic Norm: An Unsolved Murder Mystery." LSE Law, Society and Economy Papers 17.

Green, M.S. 2003. "Hans Kelsen and the Logic of Legal Systems." Alabama Law Review 54(2).

Hughes, G. 1971. "Validity and the Basic Norm." California Law Review 59(3).

Kelsen, H. 2014. Czysta Teoria Prawa. Tłum. R. Szubert, Wstępem opatrzył A. Bosiacki. Warszawa: Lexis Nexis.

2009. Pure Theory of Law. Clark, NJ: The Lawbook Exchange, Ltd.

Paulson, S. L. 1988. "An Empowerment Theory of Legal Norm.” Ratio Juris 1.

- - . 2001. "Hans Kelsen's Doctrine of Imputation." Ratio Juris 14(1).

- - . 2013. "How Merkl's Stufenbaulehre Informs Kelsen's Concept of Law." Revus (2013), nr 21.

Spaak, T. 2005. "Kelsen and Hart on the Normativity of Law." In Wahlgren, P. \& Zamboni, M. (Eds.), Perspectives on Jurisprudence. Essays in Honour of Jes Bjarup. Stockholm: Institute for Scandinavian Law: 397-414. 


\title{
Marta Zuzanna Huk (Poznań)
}

\section{Norma podstawowa w czystej teorii prawa Hansa Kelsena Basic Norm in Hans Kelsen's Pure Theory of Law}

\begin{abstract}
The aim of following paper is to indicate that the notion of Grundnorm, described by Hans Kelsen in second edition of his Pure Theory of Law (Kelsen, 1960), is in fact a necessity in every construction of normative order - understood as a coercive design. I attempt to prove this point by explaining how Kelsen as the founder of legal normativism is making a clear distinction between effectiveness and validity of basic norm, in context of existing legal order. This leads to me to a conclusion, that as long as we presuppose law as methodologically autonomous concecpt, the Grundnorm must be regarded as its integral conditio sine qua non.
\end{abstract}

Keywords: Hans Kelsen, Pure Theory of Law, Grundnorm, effectiveness of basic norm, validity of basic norm

Doi:10.14746/eip.2015.1.14 